DIW BERLIN

Discussion Papers

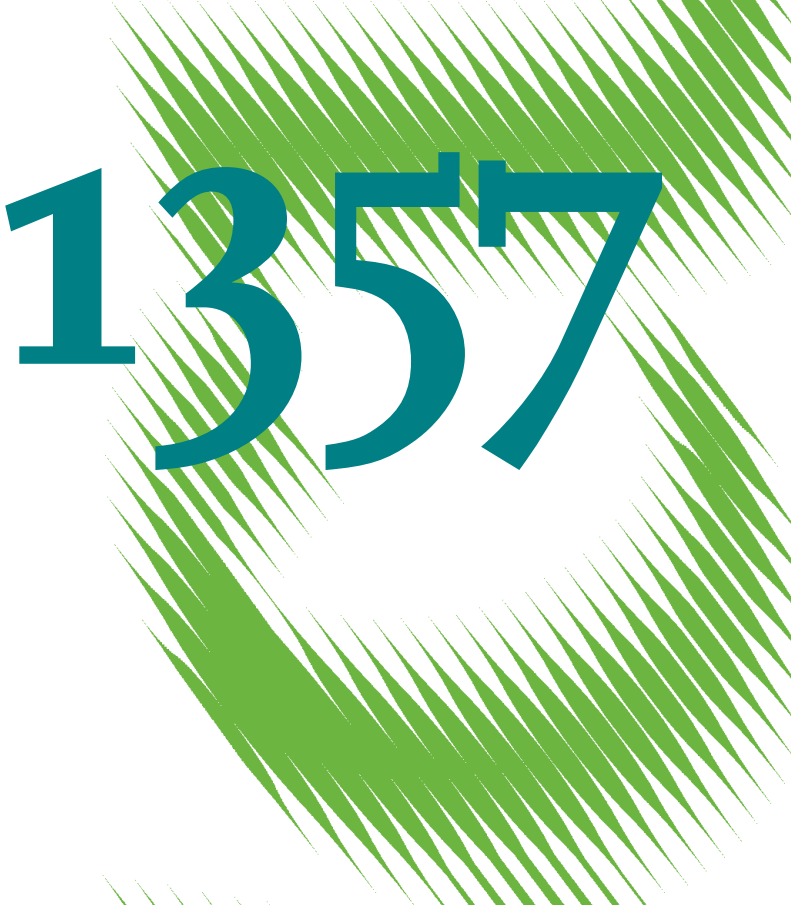

R\&D Behavior of German Manufacturing Companies during the 2008/09 Recession 
Opinions expressed in this paper are those of the author(s) and do not necessarily reflect views of the institute.

IMPRESSUM

(C) DIW Berlin, 2014

DIW Berlin

German Institute for Economic Research

Mohrenstr. 58

10117 Berlin

Tel. $+49(30) 89789-0$

Fax +49 (30) $89789-200$

http://www.diw.de

ISSN print edition $1433-0210$

ISSN electronic edition 1619-4535

Papers can be downloaded free of charge from the DIW Berlin website:

http://www.diw.de/discussionpapers

Discussion Papers of DIW Berlin are indexed in RePEc and SSRN:

http://ideas.repec.org/s/diw/diwwpp.html

http://www.ssrn.com/link/DIW-Berlin-German-Inst-Econ-Res.html 


\title{
R\&D Behavior of German Manufacturing Companies during the 2008/09 Recession
}

\author{
Alexander Eickelpasch*
}

January 2014

\begin{abstract}
This paper investigates to what extent the R\&D behavior of manufacturing companies was influenced by the 2008/09 crisis. Based on a broad official data set for German manufacturing companies, only a few companies that engaged in R\&D during 2008 gave it up in the following year. Some companies even started R\&D during crisis. R\&D expenditures declined in 2009 compared to 2008, but expanded in 2010. The development of R\&D expenditures was less volatile than sales. Probit analyses show that the occurrence of R\&D in 2009 is very much determined by engagement in R\&D in 2008 and that changes in demand are not relevant. However, fluctuation in demand proved to be relevant in the regressions computed where the intensity of R\&D expenditures was the dependent variable. This result suggests that companies reacted counter cyclically in $2008 / 09$, i.e. the reduction in $R \& D$ was smaller than the decline in demand, or the expansion of $R \& D$ expenditures was greater than the change in demand. Similar regressions for using R\&D staff as the dependent variable did not find any influence of changes in demand. The results suggest that companies see R\&D as a longer term task necessary to retain competitiveness.
\end{abstract}

JEL: E32, L60, O31

Keywords: Research and development, Business cycle, Manufacturing

* German Institute for Economic Research (DIW Berlin), Mohrenstr. 58, D-10117 Berlin, Germany, E-mail: aeickelpasch@diw.de. Helpful comments by my colleagues from the department of Firms and Markets at DIW Berlin are gratefully acknowledged. I also thank Julia Höninger and Matthias Klumpe from the Research Data Center Berlin for providing the data and for their valuable hints concerning the data characteristics. 


\section{Introduction}

In fall 2008, economic output collapsed in Germany in the wake of the global economic crisis. For many, this slump came as a surprise, even though the 2007 financial crisis, which was triggered by the U.S. economy, indicated a possible upcoming global recession. However, most had not expected that the financial crisis would affect the real economy to that extent. Even economic research institutes missed the evidence: DIW Berlin, for example, assumed in its 2009 autumn report GDP growth of 1 percent (Dreger et al. 2008). Many companies were blindsided by the speed and extent of the dramatic decline in demand during autumn 2008 (DIHK 2009). The crisis began abruptly and was the worst in Germany since World War II.

It is evident that this recession affected firms' decisions, both generally and with respect to R\&D. In fact, R\&D expenditures decreased considerably from 2008 to 2009, but subsequently then rose quite quickly in 2010 and 2011.

The picture suggests that companies behaved pro-cyclical with regard to R\&D. However, it is not automatic that a general decline in aggregate demand and production is relevant to all companies, regardless of markets served. Further, aggregate figures may be the result of opposite behavior of firms: some may reduce or even eliminate R\&D completely in order to cut costs, while others start or expand $R \& D$ in order to strengthen their own competitiveness. It is also possible that companies see R\&D as a long-term investment without accounting for fluctuations in demand.

In order to shed some more light on R\&D behavior during the crisis, an analysis of individual R\&D behavior is needed. The purpose of this paper is to investigate to what extent the R\&D behavior of manufacturing companies was influenced by the 2008/09 crisis. Based on a broad official data set for manufacturing companies, it turns out that only a few companies conducting R\&D in 2008 eliminated it in 2009; some companies even started R\&D during crisis. Firm R\&D expenditures declined from 2008 to 2009 and expanded in the following year, however, the development of expenditures was less volatile than sales. R\&D employment was more stable over time. The behavior is determined not just by individual development in demand during the crisis, but also by R\&D expenditures prior to the crisis and by firm size. These results suggest that companies see R\&D as critical for retaining competitiveness.

The rest of the paper is organized as follows: After a short description of aggregate R\&D development since 2008, a literature review on the relevance of cyclicality for R\&D and the persistence of R\&D is given. Subsequently information about the data used here is presented. The next section describes the methodology. The results of the study, including the descriptive analysis of the behavioral pattern from 2008 onwards, and the econometric investigations of the determinants of R\&D activities over that period, are presented. The paper concludes with a discussion of the results and pathways for further research. 


\section{Business R\&D in Germany since $\mathbf{2 0 0 8}$}

The cyclical sensitivity of German R\&D behavior during the 2008/09 recession is investigated by several studies. Rammer (2011) finds that companies reduced their R\&D budget only slightly, by 3 percent, compared to the innovation budget as a whole (-18 percent). Interestingly, in non-research intense manufacturing sectors R\&D budgets expanded by more than 4 percent. Kladobra and Stenke (2011) detect, on the basis of R\&D expenditure (intramural and external) data collected by the Association for the Promotion of the Sciences and Humanities in Germany (Stifterverband für die deutsche Wissenschaft), a 1 percent reduction for the whole economy and a 5 percent reduction for manufacturing. The increase was 2 percent from 2009 to 2010 and 10 percent from 2010 to 2011 (Kladroba 2013). In small companies (less than 250 employees) R\&D increased during crisis. Data on R\&D in manufacturing from the Federal Statistical Office shows a 7 percent reduction in R\&D expenditures from 2008 to 2009 followed by an increase of more than 3 percent (Eickelpasch 2012). To sum up, for Germany the crisis only had a small immediate impact on R\&D expenditure; following the crisis R\&D expenditures have grown at a much faster rate.

In order to assess actual R\&D development, it is also helpful to look at previous crises in Germany, although they were not as severe as the 2008/09 crisis. During the 2001-2005 recession, companies also did not significantly reduce their R\&D investments. Also during the 1993 recession companies responded only weakly to the crisis (Kladroba, Stenke 2011).

\section{Cyclical sensitivity and persistence of R\&D-literature survey}

There is a broad theoretical and empirical literature investigating whether business cycle development determines R\&D expenditures or not, and whether R\&D investments are pro- or counter-cyclical.

\section{Cyclical sensitivity of $R \& D$}

From a theoretical point of view there are reasons to expect that R\&D investments are counter-cyclical. Some authors refer to Schumpeter Mark I model of growth (Schumpeter 1939), according to which recessions play an important role in promoting long-term productivity growth. Aghion and Saint-Paul (1998) developed a hypothesis of opportunity costs for R\&D investments ("virtues of bad times"): In companies long-term productivity improving activities compete with short-term production activities. During recessions the rate of utilization and the profitability of production activities are low. Resources can thus be used for long-term productivity improvements, such as reorganizing production processes, renewing machinery and equipment by investments, as well as starting or expanding R\&D activities. Thus, companies are better prepared for the next upswing. Reallocation is not only probable within companies but also between companies: Inefficient companies will vanish, and workers who are let go by existing companies may be hired by new and innovative companies. According to this notion, R\&D activities are high during recessions and low during booms. This view is supported by, e.g. Davis and Haltiwanger (1990). 
However, a series of empirical studies find a positive relationship between R\&D and production. One example for pro-cyclicality of R\&D expenditures and GDP growth is Wäldle and Woitek (2004), which examines G7 countries over the 1973-2000 period.

Often credit constraints are applied for the explanation of pro-cyclicality. Aghion et al. (2012) analyze the relationship between credit constraints and R\&D behavior of French companies over the 1994-2004 period. They find that R\&D investment is counter-cyclical without credit constraints, but pro-cyclical with credit frictions. Ouyang (2011) finds for 20 U.S. manufacturing industries between 1958 and 1998 that R\&D fluctuates with demand fluctuations and proposes that liquidity constraints are an important factor for explaining the observed pro-cyclicality. Barlevy (2007) finds for U.S. manufacturing industries that R\&D expenditures, between 1959 and 2004, are pro-cyclical, i.e. R\&D tends to fall during recessions. Based on an equilibrium model, he argues that the dynamic externalities of R\&D make entrepreneurs short sighted. Companies engage too much during booms and too little during recessions. For Guellec and loannidis (1999) the levelling-off of business R\&D expenditures in OCED countries during the 1990s depends, among others, on GDP downturn, reduction in public support of R\&D, and high interest rates. Government funding affects R\&D investments in the long-term. Brockhoff and Pearson (1998) state, concerning companies in Germany and the UK, that liquidity constraints during the early 1990s recession led to a cut in R\&D expenditures and a reevaluation of R\&D projects.

Francois and Lloyd-Ellis (2009) extend the analysis from R\&D to all phases of the innovation process and develop a theory of cycles in order to integrate the empirically stated pro-cyclicality of R\&D with the Schumpeterian theory of business cycle. Similar to Shleifer (1986), they assign stages of the innovation process comprising of R\&D, commercialization and implementation to different stages of the business cycle: Companies best engage in $R \& D$ during recessions and bring their ideas and new products to the market during booms.

For the German economy, several studies are relevant: Rammer et al. (2004) study West German manufacturing companies over the 1981-2001 period, finding that R\&D expenditures depend on development of sales and productivity of companies: An increase in sales of 10 percent leads in the short run to a 2 percent increase in R\&D. They argue that a significant part of R\&D expenditures depends on orders, especially in machinery industries as here technological development is commonly part of client orders. A second reason is the pro-cyclicality of cash flow. R\&D projects are often financed by cash flow as external sourcing is difficult due to lack of securities. Smolny (2003) finds for WestGerman companies, between 1980 and 1992, that the innovation activities in manufacturing (both in terms of occurrence innovation and innovation expenditures) are positively affected by capacity utilization, medium-term demand expectations and current demand situation of an industry branch. 


\section{Persistence of $R \& D$}

There are also theoretical arguments for the view that R\&D is not responsive to economic fluctuations but rather shows persistence over time. R\&D investments are sunk costs, i.e. costs that have been incurred and cannot be reversed later (Sutton 1991). For example, once a company has started a longterm R\&D project, the outlays are lost regardless if the project is stopping ahead of schedule or it is conducted as planned. Following this notion it is assumed that companies planning R\&D activities provide for a risk against potential imponderables caused by future demand or cash flow fluctuations and thus will not question the realization of the projects when the company will get into difficulties. This would also mean that some risk adverse companies avoid R\&D activities, even though R\&D might be needed for future competitiveness. This behavior will come into effect, especially when a R\&D project is running over a longer period of time or the risk is very high and outcome is very uncertain.

There are further strands of literature contributing to explanation of the persistence of innovations. One is the notion that "success breeds success." Mansfield (1968) argues that past innovations raise the probability to innovate again, i.e. innovative success generates profits that may be reinvested in future R\&D activities. Further, evolutionary theory addresses the cumulative nature of the learning process (Rosenberg, 1976; Nelson and Winter, 1982): Knowledge is based on previous knowledge and will affect future research. Firms thus benefit from dynamic increasing returns in innovation in the form of learning. This will also enhance firms' absorptive capacity, which will permit the efficient accumulation of external knowledge (Cohen and Levinthal, 1989).

Finally, another aspect should be considered: R\&D projects are realized by researchers who incorporate tacit knowledge. If they are dismissed during recessions not only is the knowledge gone irrecoverably but competitors might hire them and make use their knowledge. It is also unlikely that the company, which dismissed researchers, would be able to reemploy the researchers later, when they were needed.

There is broad empirical work that supports the considerations of state dependency of R\&D. A recent example is Aruqé-Castells (2013) who finds, for Spanish manufacturing companies for the 1998-2009 period, that the decision to perform R\&D increases the probability for R\&D in the subsequent period. This supports his hypothesis on true state dependency. Manez et al. (2009) tests for the existence of sunk costs in Spanish manufacturing firms between 1990 and 2000; finding that prior R\&D decisions matter for current R\&D decisions. Peters (2009) investigates whether firms do R\&D permanently over time using a data set for German manufacturing and service industries for 1994 through 2002. She concludes that in most firms past R\&D determines current R\&D to a large extent. In addition to R\&D, she also investigates state dependency for innovation activities. It turns out that past innovation is an important driver for subsequent innovation. Arvanitis and Woerter (2013) find, for Swiss manufacturing companies, that 42 percent of firms with R\&D activities behaved pro-cyclically (in terms of R\&D intensity) over the 1999-2009 period; 17 percent behaved anti-cyclically, while the rest were nonsystematic. As a final example, Lee (2003) shows in the empirical part of his paper that technological capability is positive and significant to the R\&D intensity whereas sales growth has positive coefficients, which are less significant than the key determinants. In addition to R\&D there are also a series of studies on the persistence of innovation activities. Most of the studies, such as Raymond et al. (2010), Rogers 
(2004), Cefis (2003) and Filippetti, Archibugi (2011), to name a few, confirm the state dependency hypothesis.

\section{Data}

The analysis is based on data from the cost structure survey in manufacturing, in mining and extraction (Kostenstrukturerhebung im Verarbeitenden Gewerbe, im Bergbau sowie in der Gewinnung von Steinen und Erden, KSE) conducted by the Federal Statistical Office (Fritsch et al. 2004). This data is an annual survey carried out among manufacturing companies, which, since 1999, provide information on internal $R \& D$ expenditure (personnel and material costs as well as investment) and the number of persons employed in R\&D (headcount). The survey concept uses the internationally binding definitions and categories of R\&D outlined in the OECD Frascati Manual (OECD 2002). The survey also provides data on economic output and turnover, costs and cost type, as well as on employment. Among companies with 20 to 499 employees, a random sample is drawn, while companies with 500 or more employees are fully integrated into the survey. KSE comprises of almost 18,000 enterprises in 2010, 45 percent of all manufacturing companies. The downside of the KSE is that it does not capture small manufacturing enterprises with fewer than 20 employees or contract research. A further shortcoming is that the survey only gathers information on the number of persons employed in R\&D but not the number of working hours dedicated to R\&D activities. In addition KSE does not capture external R\&D, which may also be subject to economic fluctuations.

This study is based on data consisting of individual company data covering 2008 to 2010 and is provided by the official Research Data Centers of the Federal Statistical Office and the Statistical Offices of the Länder (Forschungsdatenzentren der Statistischen Ämter des Bundes und der Länder, FDZ). For details about data access see Zühlke et al. (2004). For this period a longitudinal data set was built. Companies were only included in the computations if they were recorded as manufacturing in all three years. There

are also few companies that were recorded as manufacturing in 2010 but recorded as mining in 2008 or 2009. There are also included in the analysis.

After adjustment nearly 17,800 companies are included in the data set. For nearly 87 percent, information is provided for all three years (Table 1). Less information - one or two years - is recorded for 13 percent of the companies. Reasons for this include that companies are exempted from reporting to the Federal Statistical Office if they have fewer than 20 employees, they change their product portfolio from manufacturing to other branches such as services, they were acquired by other companies, or they were closed down. There are analogous reasons why companies are legally obliged to participate in the survey. 
Table 1: Companies in Manufacturing Captured by KSE 2008 to 2010

\begin{tabular}{c|c|c|c}
\hline Frequencies & Percent & Cum. & Pattern \\
\hline 15,414 & 86.7 & 86.7 & 111 \\
854 & 4.8 & 91.5 & $1 .$. \\
827 & 4.7 & 96.1 & 11. \\
323 & 1.8 & 97.9 & .11 \\
293 & 1.7 & 99.6 &. .1 \\
52 & 0.3 & 99.9 & 1.1 \\
23 & 0.1 & 100.0 & .1. \\
\hline 17,786 & 100.0 \\
\hline Pattern: Company participated in all years (“111"), \\
in 2008 only ("1.."), in 2008 and 2009 only ("11."), \\
in 2009 and 2010 only (".11"), etc. \\
Source: FDZ, KSE, own calculations.
\end{tabular}

\section{Methodology}

The R\&D behavior of German companies is analyzed, first, by using the occurrence of R\&D as a binary variable and, second, by using the intensity of R\&D expenditures (as percentage of production) and R\&D staff (as percentage of total employment).

The use of the occurrence of R\&D as a dependent variable is chosen because a whole range firm-level studies use this type of variable (e.g. Arqué-Castels 2013, Manez et al. 2009). Thus, our results can then be compared with other studies.

In order to exploit the information potential more extensively R\&D intensities are used. For this type of variable there are also comparable studies. Most of the studies define R\&D intensity by R\&Dexpenditures (as percentage of turnover), such as Lee (2003). However, R\&D intensities can also be captured in terms of R\&D employment. This indicator provides additional information as it supposed to be the less volatile part of the firm's R\&D stock than R\&D investments or costs and it also reflects the firm's employment policy. This indicator is rarely used. KSE provides information on R\&D by expenditures and by staff, so that both indicators are used here. Intensities in R\&D expenditures are calculated as a percentage of production (sales and stock variation) and intensities in R\&D staff as a percentage of all employed persons. Both indicators can take values between 0 and 1 .

Changes in R\&D activities from 2008 to 2010

As the first step the changes in R\&D activity from one year to the next are analyzed, i.e. whether a company reduced or expanded R\&D from one year to the next year, or whether it left R\&D unchanged.

Following the hypothesis of cyclical dependence it is expected that the portion of companies that will cease R\&D from one year to the next is higher for the 2008-2009 period than for the 2009-2010 period. For the group of companies with R\&D in 2008 it is expected that R\&D will decline from 2008 to 2009, but increase from 2009 to 2010 . Following the persistence hypothesis a cyclical sensitivity would not be recognizable. 
The second step examines whether the change in R\&D is dependent on the change in the demand for companies' products or on historic R\&D activity. Hereby the two competing hypothesis-R\&D is cyclical and R\&D is persistent-are tested also considering other variables that are, according to the literature, relevant for R\&D behavior. Persistence of $R \& D$ is assumed when R\&D activity in the pre-period has a positive impact on the dependent variable. In addition, for 2010 also the R\&D activities two years ago (2008) is used as an independent factor.

In line with studies on the cyclicality of R\&D, demand is an important factor determining R\&D. In this study it is measured as the change of company's sales from one year to the next. Pro-cyclicality is assumed when the reduction in R\&D is positively correlated to changes in sales and vice versa. In addition, for 2010 the change in turnover in the pre-period is used (i.e. change in sales 2008 to 2009).

Additional factors, which are identified by the literature review and according to the information available that may also influence companies' decisions on R\&D are taken into account.

The market environment may be of relevance to R\&D behavior. The change in sales of all companies in the sample in the respective industry is applied as an indicator for the development in the market. Rammer et al. (2004) also controlled for market development, but the authors matched official aggregate data to the firms' data. It is assumed that the development of industry sales is the basis for the decision in favor or against R\&D. However, the studies by Rammer et al. (2004) did not show any significant influence.

Size is well known as a factor correlating with R\&D. The propensity to perform R\&D is closely related firm size (e.g. Cohen, Klepper 1996), but not necessarily R\&D intensity in research-based companies. For this group, R\&D activities in small companies may be even larger than in larger companies (Eickelpasch 2012). Size is here measured as the number of employees in the pre-period. In order to test for possible non-linear correspondence to R\&D second order term of employees is introduced (Wagner 2001).

KSE also provide information on business income. Business income is defined as net value added at factor costs minus gross wage and salary income as well as interest on borrowings. Business income related to production (sales and stock of produced goods) is used as an indicator for the economic surplus earned during a year. A high portion of surplus signals low liquidity constraints. Some studies reference to liquidity constraints as a factor that is typical for recessions and, hence, will lead companies to reduce $R \& D$ investments. It is expected that $R \& D$ is positively correlated with surpluses.

Interest on borrowings lowers surplus of companies. Thus, high interest payments (as percentage of production) would impede further investment in R\&D or yet lead the company to stop R\&D.

Efficiency of companies is usually positively related to R\&D. Mostly, efficiency is measured as value added per employee. This widely used specification is also applied in this study. However, in times of recession the value added per employee is typically lower than during boom periods. A better indicator would be the value added related to hours worked. However, data on volume of work is not available. In 
order to control for the misleading caused by the number of employees, the portion of part time employees on all employees is also included.

Human capital is defined as knowledge and skills and other expertise embodied in persons employed. It is measured as total labor costs (wages, salaries and employers contribution to social security costs) per employee. It is evident that human capital is very much correlated to R\&D.

Product diversification may be another relevant factor that is positively correlated with R\&D activities. Galan and Sanchez (2006) find support for the hypothesis that industry R\&D intensity positively impacts the degree of product diversification. Diversification is here measured as the portion of trade on overall sales.

KSE also collects data on subsidies. In the KSE questionnaire subsidies are defined as allowances from federal, state and local authorities or the European Communities for research and development projects or for ongoing production purposes in order to reduce the production costs or the prices of the products. By definition, not all types of subsidies are captured, such as investment grants or tax reductions (Statistisches Bundesamt 2012).

To consider the influence of foreign ownership, a dummy variable indicates whether a company is controlled by a German or a foreign owner. This information is not part of KSE but added to the sample by the Statistical Office using other sources. A company is foreign controlled when a foreign proprietor controls more than half of the voting rights of the shareholders or more than half of the shares of the company directly or indirectly (Nahm 2012).

In order to account for regional differences we differentiate between West and East Germany. Many studies show that more than 20 years after unification there is still a significant difference in the nature of R\&D in East Germany and West Germany.

The legal status of a company can be used as an additional indicator for the influence of financial constraints. Corporate entities are expected to be more likely to engage in R\&D than single businesses as it is easier for them receive external financing.

Finally, company branches are controlled for. Different from other studies, here branches are classified into two groups consisting of research intensive business lines and non-research intensive business lines (Gehrke et al. 2010). The research-intensive branch includes the chemical and pharmaceutical industries, machinery, automotive, as well as electrical and electronic engineering. It is expected that being a part of these industries is positively correlated with $R \& D$ engagement.

An overview over the independent factors, the definitions and the expected impact on R\&D is provided in table 2. 
Table 2: Explanatory variables

\begin{tabular}{|c|c|c|}
\hline Variable & Definition & Dimension \\
\hline \multirow[t]{2}{*}{$R \& D$} & in $\mathrm{t}-1$ & Occurrence, percentage, or amount \\
\hline & in $\mathrm{t}-2^{*}$ & Occurrence, percentage, or amount \\
\hline \multirow[t]{2}{*}{ Turnover } & Turnover $\mathrm{t}-1$ to $\mathrm{t}$ & Percent \\
\hline & Turnover $\mathrm{t}-2$ to $\mathrm{t}-1^{*}$ & Percent \\
\hline \multirow[t]{2}{*}{ Turnover in sector } & Turnover $\mathrm{t}-1$ to $\mathrm{t}$ & Percent \\
\hline & Turnover $\mathrm{t}-2$ to $\mathrm{t}-\mathrm{1}^{*}$ & Percent \\
\hline Size & Persons employed in $\mathrm{t}-1$ & Number \\
\hline Size squared & Persons employed squared in t-1 & Number \\
\hline Surplus & Gross operating surplus in t-1 & percent of production \\
\hline Interest & Interest of borrowed capital in t-1 & percent of production \\
\hline Productivity & Value added per employee in t-1 & Euros \\
\hline Human capital & Labor costs per employee in t-1 & Euros \\
\hline Diversification & Purchased and resold goods in t-1 & percent of turnover \\
\hline Subsidies & Subsidies in t-1 & percent of production \\
\hline Part time & Part time employees & percent of persons employed \\
\hline Ownership & $\begin{array}{l}\text { Dummy for German (0) or foreign (1) } \\
\text { ownership }\end{array}$ & dichotomous \\
\hline Region & $\begin{array}{l}\text { Dummy for location in East }(0) \text { or in } \\
\text { West Germany ( } 1)\end{array}$ & dichotomous \\
\hline Legal status & $\begin{array}{l}\text { Dummy for single business }(0) \text { or } \\
\text { corporate entity ( } 1 \text { ) }\end{array}$ & dichotomous \\
\hline \multirow[t]{4}{*}{ Market } & $\begin{array}{l}\text { Dummy for affiliation to non- } \\
\text { research intensive business lines (0) }\end{array}$ & dichotomous \\
\hline & or research-intensive business lines & \\
\hline & (1; 2-digit divisions according to & \\
\hline & NACE Rev. 2) & \\
\hline
\end{tabular}

*If applicable.

Formally, the model is

$$
R \& D_{i t}=\beta+\beta_{i} X_{i t-1}+\beta_{2} C_{i t-1}+e_{i t-1}
$$

where $R \& D$ is the dependent variable defined as R\&D engagement, R\&D intensity in expenditures, or $R \& D$ intensity in staff. $X$ comprises of the explanatory variables, such as the R\&D in the previous period, sales development of the company, sales development in the affiliated branch, size, surplus interest, productivity, human capital, diversification, subsidies and ownership. $C$ indicates the control vector with dummies for region and sector group. Index $i$ points to the company, and index $t$ to the year. Following most of the studies the explanatory factors are included with the value of the year before.

The investigation is divided into three steps, depending on the properties of the dependent variables used. As R\&D engagement is measured with a binary variable (" 0 " for no R\&D, " 1 " for R\&D) probit regressions are applied in the first step. In the second step R\&D intensity is the dependent variable. For this type of variable different approaches can be applied, depending on the assumptions of the behavior of companies. In this paper it is assumed that there is a gliding transition for a company from not 
performing R\&D to being fully engaged in R\&D. This means that the factors influencing the decision to conduct $R \& D$ are in general the same as the factors for the decision how much to invest in R\&D. For this assumption a fractional probit regressions would fit best (Papke, Wooldridge 1996, Eickelpasch, Vogel 2011). An alternative approach would be the use of a zero inflated beta regression model (Cook, Kieschnick, McCullogh 2008). However, this approach assumes another behavior, which is that a firm's decision on whether to engage in R\&D or not is different from the decision concern how much is invested in R\&D.

\section{Results}

\section{Change in R\&D activities from 2008 to 2010}

In 2008, 5470 manufacturing companies engaged in R\&D, with a few stopping R\&D efforts in 2009 (nearly 8 percent, table 3). Surprisingly, from the group of non-research based companies in 2008 , in 2009 about 4 percent started R\&D despite of crisis. This pattern of change can also be found when comparing 2009 and 2010: 7 percent of the companies engaged in R\&D in 2009 stopped in 2010, while 4 percent of companies without R\&D in 2009 started it in 2010. As the patterns for both years are similar it can be concluded that, at least for this level of analysis, the effect of the recession on R\&D behavior of companies is small and that the counter and pro-cyclical effects are more or less equal.

Differencing data by industry, size class and ownership status provides some further interesting insights (Table A1): Comparing less intensive R\&D industries from 2008 to 2009, the gap between the portion of companies that gave up R\&D out of all R\&D companies and the portion of those that started R\&D out of all non-R\&D companies was much larger than the gap in R\&D intensive branches. Further, among small companies the gap was very low. In large companies the situation is remarkably different: Here the portion of companies that started R\&D was much higher than the portion of companies that gave it up. In German owned companies the portion of companies that gave up R\&D was higher than the portion of companies that started it, while no remarkable difference is observed in the group of foreign owned companies. A similar pattern of behavior can be found when comparing 2009 to 2010. This underpins the above stated observation that the effect of recession is only marginal.

As a second step, the rates of change in R\&D expenditures from 2008 to 2009 and from 2009 to 2010 are compared for those companies which maintained R\&D in both years under comparison. From 2008 to 2009 R\&D expenditures were reduced by 5.6 percent. However, sales faced a greater drop (-18.2 percent). As an effect, $R \& D$ intensity (R\&D expenditures in percent of production) increased, from 3.1 to 3.6 percent. In the year after the recession R\&D expenditures increased. From 2009 to 2010 R\&D expenditures increased by 4.8 percent, while production increased by 17.6 percent. Accordingly, R\&D intensity dropped from 3.6 to 3.3 percent. The data show that there is a certain positive correlation between companies' production and expenditures. However, the change in R\&D expenditures is not as volatile as production developments. 
Table 3: Occurrence of R\&D, R\&D Expenditures, Production and Intensity 2008-2010

\begin{tabular}{|c|c|c|c|c|c|c|c|c|c|}
\hline \multirow[b]{2}{*}{ Compnaies with R\&D ... } & \multirow{2}{*}{$\begin{array}{l}\text { Com- } \\
\text { panies }\end{array}$} & \multicolumn{3}{|c|}{$\begin{array}{c}\text { R\&D Expenditures (m } \\
\text { Euros) }\end{array}$} & \multicolumn{3}{|c|}{ Production (m Euros) } & \multicolumn{2}{|c|}{$\begin{array}{c}\text { R\&D } \\
\text { intensity (\%) }\end{array}$} \\
\hline & & in $\mathrm{t}$ & in $t+1$ & \begin{tabular}{c|}
$t+1 \%$ \\
of $t$
\end{tabular} & in $\mathrm{t}$ & in $t+1$ & $\begin{array}{c}t+1 \% \\
\text { of } t\end{array}$ & in $\mathrm{t}$ & in $t+1$ \\
\hline \multicolumn{10}{|l|}{2008 to 2009} \\
\hline in current and in subsequent year & 5,039 & 44,785 & 42,276 & -5.6 & $1,037,569$ & 849,133 & -18.2 & 3.05 & 3.63 \\
\hline in current and not in subsequent year & 431 & 193 & - & - & 16,692 & 13,946 & -16.5 & 1.99 & 0 \\
\hline not in current but in subsequent year & 438 & - & 201 & - & 18,415 & 15,836 & -14.0 & - & 1.77 \\
\hline not in current and not in subsequent year & 10,333 & - & - & - & 434,338 & 362,202 & -16.6 & - & 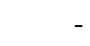 \\
\hline Comparison not possible & 906 & 1,244 & - & - & 55,796 & - & - & 1.05 & - \\
\hline Total & 17,147 & 46,221 & 42,476 & -8.1 & $1,562,810$ & $1,241,116$ & -20.6 & 1.00 & 1.18 \\
\hline \multicolumn{10}{|l|}{2009 to 2010} \\
\hline in current and in subsequent year & 4,994 & 41,847 & 43,859 & 4.8 & 837,386 & 984,553 & 17.6 & 3.57 & 3.27 \\
\hline in current and not in subsequent year & 379 & 406 & - & - & 22,109 & 20,766 & -6.1 & 1.73 & - \\
\hline not in current but in subsequent year & 434 & - & 234 & - & 16,119 & 18,785 & 16.5 & - & 2 \\
\hline not in current and not in subsequent year & 9,930 & - & 0 & - & 351,715 & 387,998 & 10.3 & - & - \\
\hline Comparison not possible & 850 & 973 & 0 & - & 41,593 & 0 & -100.0 & 1.37 & - \\
\hline Total & 16,587 & 43,226 & 44,092 & 2.0 & $1,268,921$ & $1,412,101$ & 11.3 & 1.19 & 1.09 \\
\hline
\end{tabular}

Source: FDZ, KSE, own calculations.

The differentiation by branches replicates that type of behavior (Table A2). However, there are some branches with companies that expanded R\&D although demand dropped. Even very small companies (up to 100 employees) increased R\&D expenditures while production fell. For the comparison 2009 to 2010 R\&D expenditures was less expansionary than production in all subgroups, with the exception of the food industry where R\&D expenditures declined.

Looking at the second measure available for the scope of R\&D activities, the number of R\&D employees, and the picture changes (Table 4). Opposite to R\&D expenditures R\&D staff was slightly higher, by 1.1 percent, in 2009 compared to 2008 whereas total employment dropped by 3.2 percent. From 2009 to 2010 R\&D staff grew by 3 percent, while total employment expanded by only 0.2 percent. This result reinforces the impression that $R \& D$ behavior of companies was not dramatically influenced by the recession.

The differentiation by branches replicates that type of behavior (Table A3), although there are some branches where R\&D employment declined from 2008 to 2009. This can be observed mainly in less intensive branches. However, it is not clear if the decline is an effect of the recession as a decline in R\&D employment was found in these branches for 2009 to 2010. 
Table 4: Occurrence of R\&D, R\&D Staff, Employment and Intensity 2008-2010

\begin{tabular}{|c|c|c|c|c|c|c|c|c|c|}
\hline \multirow[b]{2}{*}{ Companies with R\&D ... } & \multirow{2}{*}{$\begin{array}{c}\text { Com- } \\
\text { panies }\end{array}$} & \multicolumn{3}{|c|}{ R\&D staff (1000) } & \multicolumn{3}{|c|}{ Employment (1000) } & \multicolumn{2}{|c|}{$\begin{array}{c}\text { R\&D } \\
\text { intensity (\%) }\end{array}$} \\
\hline & & in $\mathrm{t}$ & in $t+1$ & $\begin{array}{c}t+1 \% \\
\text { of } t\end{array}$ & in $\mathrm{t}$ & in $t+1$ & $\begin{array}{c}\mathrm{t}+1 \% \\
\text { of } \mathrm{t}\end{array}$ & in $\mathrm{t}$ & in $\mathrm{t}+1$ \\
\hline \multicolumn{10}{|l|}{2008 to 2009} \\
\hline in current and in subsequent year & 4,862 & 263 & 266 & 1.1 & 2,881 & 2,788 & -3.2 & 7.29 & 7.55 \\
\hline in current and not in subsequent year & 442 & 3 & - & - & 80 & 75 & -5.4 & 4.94 & - \\
\hline not in current but in subsequent year & 448 & - & 3 & - & 81 & 81 & -0.3 & - & 5.11 \\
\hline not in current and not in subsequent year & 10,489 & - & - & - & 1,431 & 1,391 & -2.8 & - & - \\
\hline Comparison not possible & 906 & 9 & - & - & 178 & 0 & - & 2.29 & - \\
\hline Total & 17,147 & 275 & 269 & -2.2 & 4,652 & 4,336 & -6.8 & 2.31 & 2.4 \\
\hline \multicolumn{10}{|l|}{2009 to 2010} \\
\hline in current and in subsequent year & 4,822 & 266 & 273 & 3.0 & 2,772 & 2,777 & 0.2 & 7.5 & 7.6 \\
\hline in current and not in subsequent year & 381 & 4 & - & - & 78 & 77 & -1.6 & 4.96 & - \\
\hline not in current but in subsequent year & 434 & - & 3 & - & 68 & 71 & 3.3 & - & 5.78 \\
\hline not in current and not in subsequent year & 10,100 & - & - & - & 1,364 & 1,376 & 0.9 & - & - \\
\hline Comparison not possible & 850 & 8 & - & - & 173 & 0 & - & 2.33 & - \\
\hline Total & 16,587 & 278 & 276 & -0.4 & 4,455 & 4,302 & -3.4 & 2.41 & 2.49 \\
\hline
\end{tabular}

Source: FDZ, KSE, own calculations.

\section{Determinants of R\&D activities from 2008 to 2010}

The descriptive analysis so far shows that there are only a few differences in R\&D behavior over the two periods of time investigated here: During the 2008/09 recession there are only few companies that changed their status (stopped or started $R \& D$ ), the decline in $R \& D$ expenditures was less dramatic than the decline in production, and R\&D staff remains relatively unchanged even though total employment declined. In the 2009/10 period the number of companies starting R\&D is a little bit higher than the number of those stopping it, and overall R\&D expenditures and staff grew. These observations lead to the assumption that R\&D investments are relatively independent of demand during recessions.

In order to investigate R\&D behavior more thoroughly a model of company R\&D behavior is applied and statistically tested. As a first step the differences in the characteristics of the independent variables between R\&D and non R\&D companies are presented for 2009 and 2010. Table 4 shows the means and standard deviation of the variables, and Table A4 the t-tests of means for 2009, tables A5 and A6 the means, standard deviations and t-tests for 2010.

From 2008 to 2009 turnover fell on average in R\&D companies a bit more than in non R\&D companies (Table 5). This can be explained by be strong export orientation of R\&D companies. As expected R\&D companies are, on average, much larger than non R\&D companies. This corresponds to the higher labor productivity in R\&D companies compared to non R\&D companies. R\&D companies also pay higher wages on average and have a smaller share of part-time employees. The differences in surplus and interest between the two groups are negligible, although subsidies are higher in R\&D companies. One reason for the difference could be that the mean also includes companies without subsidies and the portion of non-subsidized companies is higher among the non R\&D companies than among R\&D companies. Further, not surprisingly, the portion of foreign owned companies as well as the share of 
corporate entities is higher in the group of R\&D companies. In East Germany the share of R\&D companies is lower than in West Germany. This pattern corresponds to the results of various studies on R\&D deficits in East Germany (Belitz, Eickelpasch, Lejpras 2010). With regard to branches, it is expected that the portion of R\&D companies is much higher in R\&D intensive branches, such as machinery, automotive, electrical engineering, as well as chemical and pharmaceutical industries.

Table 5: Descriptive statistics for Companies with and without R\&D expenditure in 2009

\begin{tabular}{|c|c|c|c|}
\hline & [0]No & [1]Yes & Total \\
\hline \multirow[t]{2}{*}{ Occurrence of R\&D } & 0 & 1 & 0.339 \\
\hline & (0) & (0) & $(0.473)$ \\
\hline \multirow[t]{2}{*}{ Occurrence of R\&D t-1 } & 0.0400 & 0.920 & 0.337 \\
\hline & $(0.196)$ & $(0.271)$ & $(0.473)$ \\
\hline \multirow{2}{*}{ Turnover t \% t-1 } & -0.114 & -0.132 & -0.120 \\
\hline & $(0.300)$ & $(0.265)$ & $(0.289)$ \\
\hline \multirow[t]{2}{*}{ Turnover of sector $\mathrm{t} \% \mathrm{t}-1$} & -0.151 & -0.171 & -0.158 \\
\hline & $(0.0727)$ & $(0.0668)$ & $(0.0714)$ \\
\hline \multirow[t]{2}{*}{ Persons employed } & 132.8 & 533.4 & 268.6 \\
\hline & (287.9) & (3260.9) & (1922.2) \\
\hline \multirow[t]{2}{*}{ Persons employed squared } & 100495.4 & 10915991.5 & 3766953.2 \\
\hline & $(1554828.7)$ & (358203243.9) & $(208613743.4)$ \\
\hline \multirow[t]{2}{*}{ Surplus t- $1 \%$ of production } & 0.0330 & 0.0365 & 0.0342 \\
\hline & $(0.0946)$ & $(0.108)$ & $(0.0994)$ \\
\hline \multirow[t]{2}{*}{ Interest $\mathrm{t}-1 \%$ of production } & 0.00964 & 0.0102 & 0.00982 \\
\hline & $(0.0133)$ & (0.0139) & $(0.0135)$ \\
\hline \multirow[t]{2}{*}{ Productivity t-1 Euros } & 57895.3 & 71687.5 & 62546.5 \\
\hline & $(109747.7)$ & $(109278.6)$ & $(109780.2)$ \\
\hline \multirow[t]{2}{*}{ Human capital t-1 Euros } & 36933.0 & 47059.6 & 40348.0 \\
\hline & $(13546.8)$ & $(14474.7)$ & (14669.5) \\
\hline \multirow[t]{2}{*}{ Trade $\mathrm{t}-1 \%$ of turnover } & 0.0476 & 0.0769 & 0.0575 \\
\hline & $(0.117)$ & $(0.138)$ & $(0.125)$ \\
\hline \multirow{2}{*}{ Subsidies $\mathrm{t}-1 \%$ of production } & 0.000469 & 0.00119 & 0.000713 \\
\hline & $(0.00528)$ & $(0.00913)$ & $(0.00683)$ \\
\hline \multirow{2}{*}{ Part time employees $\mathrm{t}-1 \%$ of employees } & 0.123 & 0.0837 & 0.110 \\
\hline & $(0.147)$ & $(0.0938)$ & $(0.132)$ \\
\hline \multirow[t]{2}{*}{ German ownership } & 0.909 & 0.817 & 0.878 \\
\hline & $(0.288)$ & $(0.387)$ & $(0.328)$ \\
\hline \multirow[t]{2}{*}{ Foreign ownership } & 0.0910 & 0.183 & 0.122 \\
\hline & $(0.288)$ & $(0.387)$ & $(0.328)$ \\
\hline \multirow[t]{2}{*}{ East Germany } & 0.189 & 0.160 & 0.179 \\
\hline & $(0.391)$ & $(0.367)$ & $(0.383)$ \\
\hline \multirow[t]{2}{*}{ West Germany } & 0.811 & 0.840 & 0.821 \\
\hline & $(0.391)$ & $(0.367)$ & $(0.383)$ \\
\hline \multirow[t]{2}{*}{ Single business } & 0.342 & 0.274 & 0.319 \\
\hline & $(0.474)$ & $(0.446)$ & $(0.466)$ \\
\hline \multirow[t]{2}{*}{ Corporate entity } & 0.658 & 0.726 & 0.681 \\
\hline & $(0.474)$ & $(0.446)$ & $(0.466)$ \\
\hline \multirow[t]{2}{*}{ Other branches of industry } & 0.737 & 0.429 & 0.632 \\
\hline & $(0.440)$ & $(0.495)$ & $(0.482)$ \\
\hline \multirow[t]{2}{*}{ R\&D-intensive branches of industry } & 0.263 & 0.571 & 0.368 \\
\hline & $(0.440)$ & $(0.495)$ & $(0.482)$ \\
\hline Observations & 16587 & & \\
\hline
\end{tabular}




\section{Occurrence of $R \& D$}

The results of the probit regressions for the occurrence of R\&D, both marginal effects and $p$-values, are presented in table 6. Regressions are performed for the years 2009, 2010 and for both years.

Table 6: Probit Regressions of the Occurrence of R\&D in German Manufacturing Companies 2009 and 2010

\begin{tabular}{|c|c|c|c|c|}
\hline & $\begin{array}{c}(1) \\
2009 \\
\end{array}$ & $\begin{array}{c}(2) \\
2010 \\
\end{array}$ & $\begin{array}{c}(3) \\
2009 \text { and } 2010\end{array}$ & $\begin{array}{c}(4) \\
2010 \\
\end{array}$ \\
\hline Occurrence of R\&D t-1 (d) & $\begin{array}{c}0.859 * * * \\
{[0.000]}\end{array}$ & $\begin{array}{c}0.867 * * * \\
{[0.000]}\end{array}$ & $\begin{array}{c}0.863^{* * *} \\
{[0.000]}\end{array}$ & $\begin{array}{c}0.733^{* * *} \\
{[0.000]}\end{array}$ \\
\hline Turnover $\mathrm{t} \% \mathrm{t}-1$ & $\begin{array}{l}0.0167 \\
{[0.389]}\end{array}$ & $\begin{array}{c}0.00926 \\
{[0.586]}\end{array}$ & $\begin{array}{l}0.0128 \\
{[0.329]}\end{array}$ & $\begin{array}{l}0.0231 \\
{[0.130]}\end{array}$ \\
\hline Turnover of sector $\mathrm{t} \% \mathrm{t}-1$ & $\begin{array}{l}-0.156^{*} \\
{[0.043]}\end{array}$ & $\begin{array}{l}0.219 * * \\
{[0.009]}\end{array}$ & $\begin{array}{l}0.0588 \\
{[0.278]}\end{array}$ & $\begin{array}{c}0.142 \\
{[0.200]}\end{array}$ \\
\hline Persons employed & $\begin{array}{c}0.0000992^{* * *} \\
{[0.000]}\end{array}$ & $\begin{array}{c}0.0000563 * * * \\
{[0.001]}\end{array}$ & $\begin{array}{c}0.0000773^{* * *} \\
{[0.000]}\end{array}$ & $\begin{array}{c}0.0000483^{* *} \\
{[0.006]}\end{array}$ \\
\hline Persons employed squared & $\begin{array}{c}-6.60 \mathrm{e}-10 * * * \\
{[0.000]}\end{array}$ & $\begin{array}{c}-3.75 e-10^{* *} \\
{[0.001]}\end{array}$ & $\begin{array}{c}-5.14 \mathrm{e}-10 * * * \\
{[0.000]}\end{array}$ & $\begin{array}{c}-3.21 \mathrm{e}-10^{* *} \\
{[0.007]}\end{array}$ \\
\hline Surplus $\mathrm{t}-1 \%$ of production & $\begin{array}{c}0.135 * * \\
{[0.008]}\end{array}$ & $\begin{array}{l}0.0831 \\
{[0.087]}\end{array}$ & $\begin{array}{l}0.100 * * \\
{[0.004]}\end{array}$ & $\begin{array}{l}0.0743 \\
{[0.153]}\end{array}$ \\
\hline Interest $\mathrm{t}-1 \%$ of production & $\begin{array}{c}0.832 \\
{[0.056]}\end{array}$ & $\begin{array}{l}1.112^{* *} \\
{[0.007]}\end{array}$ & $\begin{array}{c}0.994 * * * \\
{[0.001]}\end{array}$ & $\begin{array}{l}0.994^{*} \\
{[0.014]}\end{array}$ \\
\hline Productivity t-1 Euros & $\begin{array}{c}-0.000000105^{* * *} \\
{[0.001]}\end{array}$ & $\begin{array}{c}-0.000000119 * * \\
{[0.006]}\end{array}$ & $\begin{array}{c}-0.000000109 * * * \\
{[0.000]}\end{array}$ & $\begin{array}{c}-0.000000113^{*} \\
{[0.010]}\end{array}$ \\
\hline Human capital t-1 Euros & $\begin{array}{c}0.00000359 * * * \\
{[0.000]}\end{array}$ & $\begin{array}{c}0.00000314^{* * *} \\
{[0.000]}\end{array}$ & $\begin{array}{c}0.00000340 * * * \\
{[0.000]}\end{array}$ & $\begin{array}{c}0.00000275^{* * *} \\
{[0.000]}\end{array}$ \\
\hline Trade $\mathrm{t}-1 \%$ of turnover & $\begin{array}{c}0.142 * * * \\
{[0.001]}\end{array}$ & $\begin{array}{l}0.0878 \\
{[0.053]}\end{array}$ & $\begin{array}{c}0.113^{* * *} \\
{[0.000]}\end{array}$ & $\begin{array}{l}0.0548 \\
{[0.254]}\end{array}$ \\
\hline Subsidies $\mathrm{t}-1 \%$ of production & $\begin{array}{c}0.279 \\
{[0.648]}\end{array}$ & $\begin{array}{c}0.844 \\
{[0.060]}\end{array}$ & $\begin{array}{c}0.678 \\
{[0.052]}\end{array}$ & $\begin{array}{c}0.712 \\
{[0.085]}\end{array}$ \\
\hline $\begin{array}{l}\text { Part time employees } \mathrm{t}-1 \% \text { of } \\
\text { employees }\end{array}$ & $\begin{array}{l}0.0190 \\
{[0.695]}\end{array}$ & $\begin{array}{l}-0.0973 \\
{[0.057]}\end{array}$ & $\begin{array}{l}-0.0496 \\
{[0.156]}\end{array}$ & $\begin{array}{r}-0.0782 \\
{[0.136]}\end{array}$ \\
\hline German ownership (d) & $\begin{array}{l}0.0193 \\
{[0.218]}\end{array}$ & $\begin{array}{l}-0.0156 \\
{[0.373]}\end{array}$ & $\begin{array}{c}0.00266 \\
{[0.821]}\end{array}$ & $\begin{array}{r}-0.0133 \\
{[0.475]}\end{array}$ \\
\hline East Germany (d) & $\begin{array}{l}0.0324 \\
{[0.058]}\end{array}$ & $\begin{array}{l}0.0286 \\
{[0.103]}\end{array}$ & $\begin{array}{c}0.0292^{*} \\
{[0.016]}\end{array}$ & $\begin{array}{l}0.0315 \\
{[0.085]}\end{array}$ \\
\hline Single business (d) & $\begin{array}{l}-0.0191 \\
{[0.098]}\end{array}$ & $\begin{array}{l}0.0110 \\
{[0.372]}\end{array}$ & $\begin{array}{c}-0.00534 \\
{[0.526]}\end{array}$ & $\begin{array}{l}0.0158 \\
{[0.215]}\end{array}$ \\
\hline $\begin{array}{l}\text { Other branches of industry } \\
\text { (d) } \\
\text { Year }\end{array}$ & $\begin{array}{c}-0.0668 * * * \\
{[0.000]}\end{array}$ & $\begin{array}{c}-0.0986 * * * \\
{[0.000]}\end{array}$ & $\begin{array}{c}-0.0886 * * * \\
{[0.000]} \\
-0.00194 \\
{[0.890]}\end{array}$ & $\begin{array}{c}-0.0838 * * * \\
{[0.000]}\end{array}$ \\
\hline Occurrence of R\&D t-2 (d) & & & & $\begin{array}{c}0.338 * * * \\
{[0.000]}\end{array}$ \\
\hline Turnover $\mathrm{t}-2 \% \mathrm{t}-1$ & & & & $\begin{array}{c}0.00941 \\
{[0.710]}\end{array}$ \\
\hline Turnover of sector $\mathrm{t}-1 \% \mathrm{t}-2$ & & & & $\begin{array}{r}-0.0628 \\
{[0.562]}\end{array}$ \\
\hline $\begin{array}{l}\text { Pseudo } R^{2} \\
\text { Observations }\end{array}$ & $\begin{array}{l}0.690 \\
16180\end{array}$ & $\begin{array}{l}0.699 \\
15662\end{array}$ & $\begin{array}{l}0.694 \\
31842\end{array}$ & $\begin{array}{l}0.717 \\
15357\end{array}$ \\
\hline
\end{tabular}

Marginal effects; p-values in brackets.

Source: FDZ, KSE, own calculations.

(d) for discrete change of dummy variable from 0 to 1

$* \mathrm{p}<0.05,{ }^{* *} \mathrm{p}<0.01, * * * \mathrm{p}<0.001$ 
In the 2009 regression, the hypothesis of R\&D persistence is tested by the occurrence of R\&D in 2008. A positive sign of the occurrence of R\&D in 2008 increases the probability for a company to perform R\&D in 2009. The hypothesis of business cycle dependence is tested by the influence of the development in turnover from 2008 to 2009. As a second variable for business cycle dependence the change in demand of the branch is used. For both variables a positive sign means that growth (decay) in turnover from 2008 to 2009 increases (decreases) the probability for a company to engage in R\&D in 2009. In the same manner, for comparison, a probit regression is conducted for 2010.

Additionally, a regression is conducted for 2010 in order to test for longer term effects of the 2008 recession by including the occurrence of $R \& D$ in 2008 and 2009 and the development of turnover from 2008 to 2009 and from 2009 to 2010.

By and large, the regressions confirm the impression derived from the descriptive analysis. The occurrence of R\&D in 2008 has a positive sign and is significant, i.e. the probability to perform R\&D in 2009 is dependent on R\&D in 2008. The development of turnover from 2008 to 2009 also has a positive sign, but is not significant. This picture-persistence of R\&D and no relevance of change in demand-is confirmed by both 2010 regressions.

The expected signs are found for some of the other factors. In the 2009 estimation the marginal effect of size is significant and positive while the effect of the squared value is significant and negative. A positive impact of surplus can also be confirmed by the estimation. Labor productivity has a negative influence. This is surprising at first glance. However, this may be the result of the fact that in recessions $R \& D$ companies suffer much more from the downturn due to export exposure than do non R\&D companies, which led to a lower value added per capita. In line with expectations from the literature, human capital is a positive influence. Finally, product diversification, measured by the portion of trade on turnover, has a positive impact of the propensity for R\&D. As expected there is also a significant dependence on the affiliation to research intensive branches. By and large, the relevance of the mentioned factors are also relevant for 2010. The extended 2010 regression, which also includes the change of turnover and the occurrence of R\&D two years before, also delivers similar results. As the results are not very different for both years, it can be assumed that the behavior of companies is quite stable.

\section{$R \& D$ expenditures}

The extended regression for the intensity in expenditures gives a more differentiated picture (Table 7). There are two important differences in the probit regression results. First, change in turnover from 2008 to 2009 has a significant and negative influence on R\&D intensity and, second, the marginal effect of $R \& D$ activity in 2008 is much lower than in the R\&D occurrence regression.

The negative relationship between R\&D intensity and change in demand can be taken as an indicator for anti-cyclical behavior as it shows that companies did not reduce R\&D expenditures to the degree that demand fell, or that they even expanded R\&D expenditures while demand leveled off or declined. 
It also must be mentioned that size-although positive and significant-is less relevant for the realization of a certain degree of R\&D activity than for the decision to start R\&D.

Finally, the regional affiliation of companies also influences R\&D activities. Companies in West Germany are more likely to engage in R\&D than those in East Germany. For 2010, similar results are found.

The 2010 regression, including turnover 2008 to 2009 and 2008 R\&D intensity, show that decline during the crisis was no longer relevant, while 2008 R\&D intensity had a positive effect on 2010 R\&D intensity.

Table 7: Fractional Probit Regressions of R\&D Expenditure in German Manufacturing Companies

\begin{tabular}{|c|c|c|c|c|}
\hline & $\begin{array}{c}(1) \\
2009\end{array}$ & $\begin{array}{c}(2) \\
2010\end{array}$ & $\begin{array}{c}(3) \\
2009 \text { and } 2010\end{array}$ & $\begin{array}{c}14) \\
2010\end{array}$ \\
\hline \multirow{2}{*}{$\begin{array}{l}\text { R\&D expenditure } t-1 \% \text { of } \\
\text { production }\end{array}$} & $0.139 * * *$ & $0.123 * * *$ & $0.132 * * *$ & $0.0924 * * *$ \\
\hline & [17.32] & [28.04] & [32.85] & [14.30] \\
\hline \multirow[t]{2}{*}{ Turnover $\mathrm{t} \% \mathrm{t}-1$} & $-0.00356 * * *$ & $-0.00176^{*}$ & $-0.00230 * * *$ & $-0.00220 * *$ \\
\hline & {$[-5.54]$} & {$[-2.37]$} & {$[-3.68]$} & {$[-3.26]$} \\
\hline \multirow[t]{2}{*}{ Turnover of sector $\mathrm{t} \% \mathrm{t}-1$} & -0.00328 & $0.00356^{*}$ & -0.00116 & 0.00346 \\
\hline & {$[-1.35]$} & {$[2.17]$} & {$[-0.85]$} & {$[1.84]$} \\
\hline \multirow[t]{2}{*}{ Persons employed } & $0.000000191 * *$ & $0.000000124 *$ & $0.000000157^{* * *}$ & 0.000000106 \\
\hline & [2.75] & {$[2.17]$} & [3.39] & {$[1.81]$} \\
\hline \multirow[t]{2}{*}{ Persons employed squared } & $-1.48 \mathrm{e}-12^{*}$ & $-9.76 e-13$ & $-1.21 \mathrm{e}-12^{* *}$ & $-8.24 e-13$ \\
\hline & {$[-2.04]$} & {$[-1.95]$} & {$[-2.73]$} & {$[-1.65]$} \\
\hline \multirow[t]{2}{*}{ Surplus t- $1 \%$ of production } & $0.00782 * *$ & 0.00350 & 0.00514 & 0.00254 \\
\hline & [2.97] & [0.95] & [1.88] & {$[0.73]$} \\
\hline \multirow{2}{*}{$\begin{array}{l}\text { Interest } \mathrm{t}-1 \% \text { of } \\
\text { production }\end{array}$} & 0.0260 & 0.0192 & $0.0238 *$ & 0.00711 \\
\hline & [1.93] & {$[1.34]$} & {$[2.20]$} & [0.59] \\
\hline \multirow[t]{2}{*}{ Productivity t-1 Euros } & $-1.80 \mathrm{e}-08 * * *$ & $-1.15 e-08$ & $-1.37 e-08^{*}$ & $-9.99 e-09$ \\
\hline & {$[-3.66]$} & {$[-1.49]$} & {$[-2.55]$} & {$[-1.46]$} \\
\hline \multirow[t]{2}{*}{ Human capital t-1 Euros } & $0.000000143 * * *$ & $0.000000110 * * *$ & $0.000000124 * * *$ & $9.11 \mathrm{e}-08^{* * *}$ \\
\hline & {$[8.66]$} & [7.12] & {$[10.39]$} & [6.04] \\
\hline \multirow[t]{2}{*}{ Trade $\mathrm{t}-1 \%$ of turnover } & $0.00425 * * *$ & $0.00331 * * *$ & $0.00375 * * *$ & $0.00346 * * *$ \\
\hline & {$[6.46]$} & [4.17] & [7.24] & {$[4.48]$} \\
\hline \multirow{2}{*}{$\begin{array}{l}\text { Subsidies } \mathrm{t}-1 \% \text { of } \\
\text { production }\end{array}$} & -0.00963 & -0.0129 & -0.0110 & -0.0189 \\
\hline & {$[-0.43]$} & {$[-0.69]$} & {$[-0.74]$} & {$[-0.98]$} \\
\hline \multirow{2}{*}{$\begin{array}{l}\text { Part time employees t-1 \% } \\
\text { of employees }\end{array}$} & -0.000789 & $-0.00276^{*}$ & $-0.00211^{*}$ & $-0.00359 * *$ \\
\hline & {$[-0.59]$} & {$[-2.14]$} & {$[-2.25]$} & {$[-2.71]$} \\
\hline \multirow[t]{2}{*}{ German ownership (d) } & -0.00000351 & -0.000226 & -0.000118 & -0.000173 \\
\hline & {$[-0.01]$} & {$[-0.70]$} & {$[-0.46]$} & {$[-0.54]$} \\
\hline \multirow[t]{2}{*}{ East Germany (d) } & $0.00124^{* *}$ & $0.00177^{* * *}$ & $0.00146 * * *$ & $0.00147^{* * *}$ \\
\hline & [2.86] & [4.11] & [4.80] & [3.63] \\
\hline \multirow[t]{2}{*}{ Single business (d) } & -0.000396 & $-0.000553 *$ & $-0.000502 * *$ & -0.000434 \\
\hline & {$[-1.66]$} & {$[-2.34]$} & {$[-2.96]$} & {$[-1.79]$} \\
\hline \multirow[t]{2}{*}{ Year } & & & -0.000113 & \\
\hline & & & {$[-0.32]$} & \\
\hline \multirow{4}{*}{$\begin{array}{l}\text { R\&D expenditure } t-2 \% \text { of } \\
\text { production } \\
\text { Turnover } t-2 \% t-1\end{array}$} & & & & $0.0427^{* * *}$ \\
\hline & & & & [5.94] \\
\hline & & & & -0.000109 \\
\hline & & & & {$[-0.21]$} \\
\hline \multirow[t]{2}{*}{ Turnover of sector $\mathrm{t}-1 \% \mathrm{t}-2$} & & & & -0.000223 \\
\hline & & & & {$[-0.11]$} \\
\hline $\mathrm{AIC}$ & 1358.8 & 1246.8 & 2575.7 & 1213.3 \\
\hline Observations & 16178 & 15661 & 31839 & 15356 \\
\hline
\end{tabular}

Marginal effects; $t$ statistics in brackets

Source: FDZ, KSE, own calculations.

(d) for discrete change of dummy variable from 0 to 1

* $p<0.05,{ }^{* *} p<0.01,{ }^{* * *} p<0.001$ 


\section{R\&D staff}

Complementary to the regression for R\&D expenditures the data also allows for the importance of the crisis on R\&D employment to be assessed. The results are similar to those for R\&D expenditures (Table 8). However, there is one important difference: The development of sales does not influence R\&D intensity in either year.

Table 8: Fractional Probit Regressions of R\&D Staff in German Manufacturing Companies

\begin{tabular}{|c|c|c|c|c|}
\hline & $\begin{array}{c}(1) \\
2009\end{array}$ & $\begin{array}{c}(2) \\
2010\end{array}$ & $\begin{array}{c}(3) \\
2009 \text { and } 2010\end{array}$ & $\begin{array}{c}(4) \\
2010\end{array}$ \\
\hline \multirow{2}{*}{$\begin{array}{l}\text { R\&D employees } t-1 \% \text { of } \\
\text { employees }\end{array}$} & $0.188^{* * *}$ & $0.193 * * *$ & $0.191^{* * *}$ & $0.155^{* * *}$ \\
\hline & [27.99] & [45.85] & [43.26] & [15.41] \\
\hline \multirow[t]{2}{*}{ Turnover t \% t-1 } & -0.00130 & -0.0000313 & -0.000325 & -0.000235 \\
\hline & {$[-1.69]$} & {$[-0.05]$} & {$[-0.69]$} & {$[-0.37]$} \\
\hline \multirow{2}{*}{ Turnover of sector $\mathrm{t} \% \mathrm{t}-1$} & -0.00231 & $0.0110 * * *$ & $0.00414^{*}$ & $0.00993 * *$ \\
\hline & {$[-0.73]$} & [3.67] & {$[2.07]$} & {$[2.88]$} \\
\hline \multirow[t]{2}{*}{ Persons employed } & $0.000000304 * *$ & 0.000000172 & $0.000000234^{* *}$ & 0.000000159 \\
\hline & [2.69] & [1.52] & {$[2.93]$} & {$[1.45]$} \\
\hline \multirow[t]{2}{*}{ Persons employed squared } & $-2.25 e-12^{*}$ & $-1.22 \mathrm{e}-12$ & $-1.68 e-12^{*}$ & $-1.10 e-12$ \\
\hline & {$[-1.97]$} & {$[-1.25]$} & {$[-2.27]$} & {$[-1.16]$} \\
\hline \multirow[t]{2}{*}{ Surplus t- $1 \%$ of production } & $0.00768 * *$ & $0.00500 *$ & $0.00597^{* * *}$ & $0.00511^{*}$ \\
\hline & [2.65] & [2.47] & [3.47] & [2.31] \\
\hline \multirow[t]{2}{*}{ Interest t- $1 \%$ of production } & 0.0294 & $0.0438 * *$ & $0.0396 * * *$ & $0.0465 * *$ \\
\hline & [1.87] & {$[2.95]$} & [3.58] & {$[2.80]$} \\
\hline \multirow{2}{*}{ Productivity t-1 Euros } & $-9.36 \mathrm{e}-09 *$ & $-9.93 e-09$ & $-9.49 \mathrm{e}-09 * *$ & $-1.01 e-08$ \\
\hline & {$[-2.11]$} & {$[-1.87]$} & {$[-2.81]$} & {$[-1.80]$} \\
\hline \multirow[t]{2}{*}{ Human capital t-1 Euros } & $0.000000178 * * *$ & $0.000000165 * * *$ & $0.000000171 * * *$ & $0.000000153^{* * *}$ \\
\hline & {$[6.85]$} & {$[8.08]$} & {$[10.10]$} & {$[7.60]$} \\
\hline \multirow[t]{2}{*}{ Trade $\mathrm{t}-1 \%$ of turnover } & $0.0107 * * *$ & $0.00921 * * *$ & $0.00991 * * *$ & $0.00909 * * *$ \\
\hline & [8.46] & [7.32] & [11.10] & [7.14] \\
\hline \multirow[t]{2}{*}{ Subsidies $\mathrm{t}-1 \%$ of production } & -0.0117 & $-0.0735^{*}$ & -0.0423 & $-0.0835^{*}$ \\
\hline & {$[-0.40]$} & {$[-2.22]$} & {$[-1.86]$} & {$[-2.49]$} \\
\hline \multirow{2}{*}{$\begin{array}{l}\text { Part time employees } \mathrm{t}-1 \% \text { of } \\
\text { employees }\end{array}$} & $-0.00519 * *$ & $-0.00597 * *$ & $-0.00614 * * *$ & $-0.00657 * *$ \\
\hline & {$[-2.59]$} & {$[-2.98]$} & [-4.39] & {$[-3.22]$} \\
\hline \multirow[t]{2}{*}{ German ownership (d) } & -0.000468 & -0.000842 & -0.000658 & -0.000839 \\
\hline & {$[-0.71]$} & {$[-1.54]$} & {$[-1.50]$} & {$[-1.51]$} \\
\hline \multirow[t]{2}{*}{ East Germany (d) } & $0.00175^{*}$ & $0.00238 * * *$ & $0.00198 * * *$ & $0.00217^{* *}$ \\
\hline & [2.28] & [3.42] & [3.82] & {$[3.13]$} \\
\hline \multirow[t]{2}{*}{ Single business (d) } & -0.000538 & -0.000215 & -0.000409 & -0.0000789 \\
\hline & {$[-1.22]$} & {$[-0.53]$} & {$[-1.35]$} & {$[-0.19]$} \\
\hline \multirow[t]{2}{*}{ Year } & & & -0.000549 & \\
\hline & & & {$[-1.03]$} & \\
\hline \multirow{2}{*}{$\begin{array}{l}\text { R\&D employees } t-2 \% \text { of } \\
\text { employees }\end{array}$} & & & & $0.0444 * * *$ \\
\hline & & & & {$[4.25]$} \\
\hline \multirow[t]{2}{*}{ Turnover t-2 \% t-1 } & & & & -0.000816 \\
\hline & & & & {$[-0.84]$} \\
\hline \multirow[t]{2}{*}{ Turnover of sector $\mathrm{t}-1 \% \mathrm{t}-2$} & & & & 0.0000825 \\
\hline & & & & [0.02] \\
\hline AIC & 2238.3 & 2196.8 & 4406.5 & 2151.3 \\
\hline Observations & 16180 & 15662 & 31842 & 15357 \\
\hline
\end{tabular}

Marginal effects; t statistics in brackets

Source: FDZ, KSE, own calculations.

(d) for discrete change of dummy variable from 0 to 1

$* p<0.05, * * p<0.01, * * * p<0.001$ 


\section{Conclusion}

R\&D expenditures decreased considerably during 2008/09 crisis and quickly increased in 2010 and 2011. The aggregate picture suggests that companies behave pro-cyclical when it comes to R\&D. However, aggregate figures may be the result opposite behavior of firms: of those which reduce or even stop R\&D completely in order to cut costs and those which expand or even start R\&D in order to strengthen its own competitiveness. It is also possible that companies see R\&D as a long-term investment and thus budget for it without accounting for fluctuations in demand.

In order to shed some more light on the circumstances of R\&D behavior during crisis this paper investigates to what extent the R\&D behavior of manufacturing companies was influenced by the 2008/09 crisis. Based on a broad official data set for manufacturing companies, only a few companies that engaged in R\&D during 2008 gave it up in the following year. Some companies even started R\&D during crisis. R\&D expenditures declined in 2009 compared to 2008, but expanded in 2010. The development of R\&D expenditures was less volatile than sales.

Probit analyses show that the occurrence of R\&D in 2009 is very much determined by engagement in $R \& D$ in 2008 and that changes in demand are not relevant. However, fluctuation in demand proved to be relevant in the regressions computed where the intensity of R\&D expenditures was the dependent variable. This result suggests that companies reacted counter cyclically in $2008 / 09$, i.e. the reduction in $R \& D$ was smaller than the decline in demand, or the expansion of R\&D expenditures was greater than the change in demand. Similar regressions for using R\&D staff as the dependent variable did not find any influence of changes in demand.

One explanation for these results is that companies see R\&D as a longer term task necessary to retain competitiveness. This interpretation is supported by the fact that R\&D activities, at least in the German economy, are typically organized as projects with durations of two or more years (Grave, Kladroba 2013: 50). This means, that R\&D activities are mostly planned as mid-term projects with a low probability of stopping it ahead of schedule.

The result that R\&D staff is even less volatile than R\&D expenditures is also caused by the fact that most $R \& D$ expenditures are for engineers or support staff. One study reports that 63 percent of expenditures are personnel costs (Kladroba 2013: 36). This means that letting researchers go implies a considerable loss for the knowledge base of a company which can note easily be substituted for during boom periods. Further reasons for the low volatility of R\&D staff are the usage of short-time working allowances ("Kurzarbeitergeld") by the Federal Employment Agency to companies during crisis (Kladroba, Stenke 2011) and the massive increase in the volume of the R\&D schemes funded by the Federal Ministry of Economy and Technology (Belitz, Eickelpasch, Lejpras 2012). However, these effects cannot be investigated in the framework of KSE data.

The study contributes to the literature on cyclicality and persistence of R\&D behavior by investigating the R\&D behavior in German manufacturing over the 2008 to 2010 period. However, one has to be careful to draw general conclusions as the three year period under study is quite short. Clearly it would be optimal to study a longer period of time in order to investigate the relevance of business cycles for 
R\&D in a more general way. The KSE data allows for an extension once data for the years 2011 are available. 


\section{Appendix}

Table A1: Occurrence of R\&D by Subgroups of Companies 2008-2010

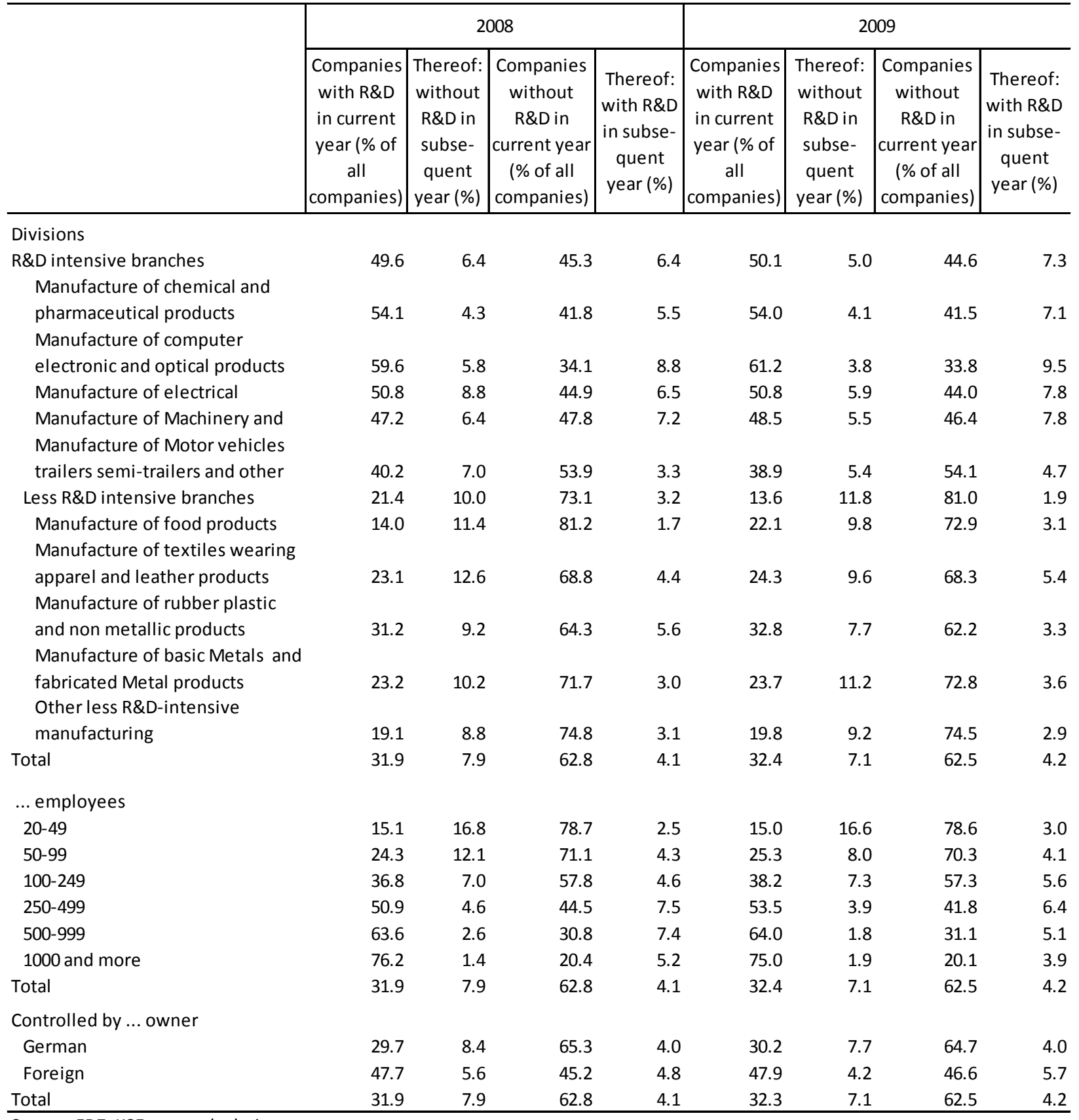

Source: FDZ, KSE, own calculations. 
Table A2: R\&D Expenditures, Production and Intensity by Subgroups 2008-2010

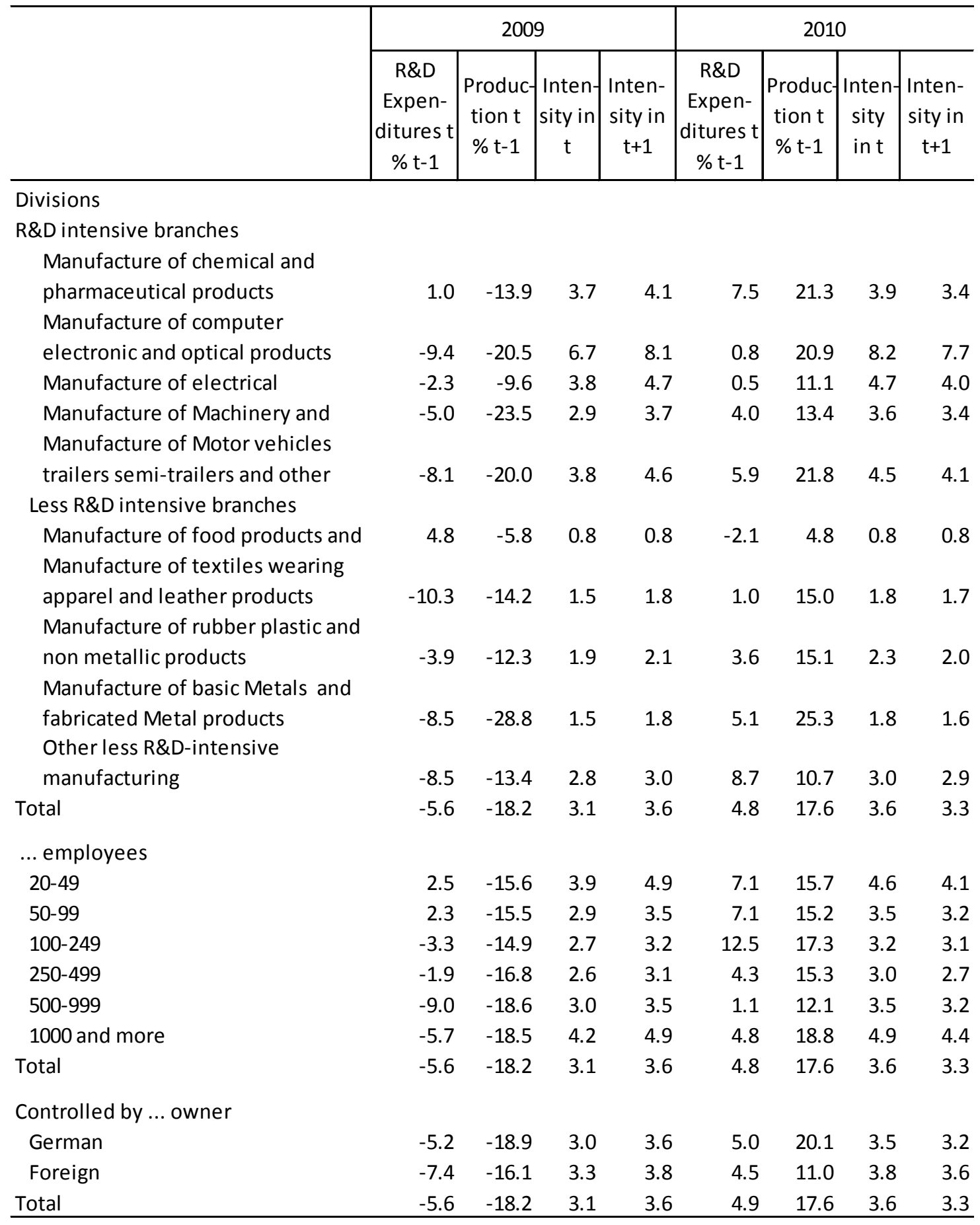

Source: FDZ, KSE, own calculations. 
Table A3: R\&D Staff, Total Employment and Intensity by Subgroups 2008-2010

\begin{tabular}{|c|c|c|c|c|c|c|c|c|}
\hline & \multicolumn{4}{|c|}{2009} & \multicolumn{4}{|c|}{2010} \\
\hline & $\begin{array}{c}\text { R\&D } \\
\text { staff } t \\
\% t-1\end{array}$ & $\begin{array}{c}\text { Employ- } \\
\text { ment t } \\
\% \mathrm{t}-1\end{array}$ & $\begin{array}{c}\text { Inten- } \\
\text { sity } \\
\text { in t }\end{array}$ & $\begin{array}{c}\text { Inten- } \\
\text { sity in } \\
t+1\end{array}$ & $\begin{array}{c}\text { R\&D } \\
\text { staff } t \\
\% \mathrm{t}-1\end{array}$ & $\begin{array}{c}\text { Employ } \\
\text { ment t } \\
\% \mathrm{t}-1\end{array}$ & $\begin{array}{c}\text { Inten- } \\
\text { sity } \\
\text { in t }\end{array}$ & $\begin{array}{c}\text { Inten- } \\
\text { sity in } \\
t+1\end{array}$ \\
\hline \multicolumn{9}{|l|}{ Divisions } \\
\hline \multicolumn{9}{|l|}{ R\&D intensive branches } \\
\hline \multicolumn{9}{|l|}{ Manufacture of chemical and } \\
\hline \multicolumn{9}{|l|}{ Manufacture of computer } \\
\hline electronic and optical products & 5.2 & -3.6 & 15.2 & 15.8 & -1.3 & -1.3 & 15.8 & 16.2 \\
\hline Manufacture of electrical & -0.3 & -2.9 & 8.9 & 9.1 & -0.3 & 3.4 & 9.2 & 9.3 \\
\hline Manufacture of Machinery and & -0.5 & -4.1 & 7.0 & 7.2 & 5.4 & -0.2 & 7.0 & 7.2 \\
\hline \multicolumn{9}{|l|}{ Manufacture of Motor vehicles } \\
\hline trailers semi-trailers and other & 2.0 & -4.0 & 9.2 & 9.9 & 4.2 & 0.7 & 10.0 & 10.3 \\
\hline \multicolumn{9}{|l|}{ Less R\&D intensive branches } \\
\hline Manufacture of food products and & -1.5 & -0.5 & 3.2 & 3.4 & 12.8 & -0.5 & 3.3 & 3.4 \\
\hline \multicolumn{9}{|l|}{ Manufacture of textiles wearing } \\
\hline apparel and leather products & -3.1 & -6.2 & 4.8 & 5.2 & -9.0 & -0.7 & 4.9 & 4.9 \\
\hline \multicolumn{9}{|l|}{ Manufacture of rubber plastic and } \\
\hline non metallic products & -3.3 & -3.2 & 4.2 & 4.3 & -0.6 & 0.2 & 4.6 & 4.5 \\
\hline \multicolumn{9}{|l|}{ Manufacture of basic Metals and } \\
\hline fabricated Metal products & -1.6 & -4.2 & 3.7 & 3.9 & 2.4 & -0.9 & 3.9 & 3.8 \\
\hline \multicolumn{9}{|l|}{ Other less R\&D-intensive } \\
\hline manufacturing & 2.5 & -1.8 & 6.1 & 6.3 & 2.4 & -0.3 & 6.2 & 6.2 \\
\hline Total & 1.1 & -3.2 & 7.3 & 7.6 & 3.0 & 0.2 & 7.5 & 7.6 \\
\hline \multicolumn{9}{|l|}{... employees } \\
\hline $20-49$ & 0.7 & -0.7 & 11.5 & 11.6 & 2.5 & 3.4 & 11.5 & 11.4 \\
\hline $50-99$ & 1.1 & -1.5 & 7.8 & 8.0 & 1.8 & 1.6 & 7.8 & 7.9 \\
\hline $100-249$ & 2.2 & -3.2 & 6.1 & 6.5 & 3.8 & 1.1 & 6.5 & 6.7 \\
\hline $250-499$ & 0.8 & -3.2 & 5.6 & 5.9 & -0.5 & 0.3 & 5.8 & 5.8 \\
\hline $500-999$ & -0.6 & -3.8 & 6.3 & 6.5 & 1.5 & -1.1 & 6.2 & 6.4 \\
\hline 1000 and more & 1.3 & -3.2 & 8.8 & 9.2 & 3.4 & 0.3 & 9.4 & 9.8 \\
\hline Total & 1.1 & -3.2 & 7.3 & 7.6 & 3.0 & 0.2 & 7.5 & 7.6 \\
\hline \multicolumn{9}{|l|}{ Controlled by ... owner } \\
\hline German & 1.6 & -2.8 & 7.1 & 7.4 & 3.3 & 0.5 & 7.3 & 7.4 \\
\hline Foreign & -0.4 & -4.9 & 8.0 & 8.2 & 2.4 & -0.9 & 8.2 & 8.5 \\
\hline Total & 1.1 & -3.2 & 7.3 & 7.6 & 3.1 & 0.2 & 7.5 & 7.6 \\
\hline
\end{tabular}

Source: FDZ, KSE, own calculations. 
Table A4: Differences in Means for Companies with and without R\&D in 2009

\begin{tabular}{|c|c|c|}
\hline & $\begin{array}{c}(1) \\
\text { Means }\end{array}$ & \\
\hline Occurrence of R\&D t-1 & $-0.880^{* * *}$ & $(-236.41)$ \\
\hline Turnover $\mathrm{t} \% \mathrm{t}-1$ & $0.0184^{* * *}$ & (3.84) \\
\hline Turnover of sector $\mathrm{t} \% \mathrm{t}-1$ & $0.0197^{* * *}$ & $(16.76)$ \\
\hline Persons employed & $-400.6^{* * *}$ & $(-12.77)$ \\
\hline Persons employed squared & $-10815496.1^{* *}$ & $(-3.16)$ \\
\hline Surplus t- $1 \%$ of production & $-0.00357^{*}$ & $(-2.16)$ \\
\hline Interest $\mathrm{t}-1 \%$ of production & $-0.000531^{*}$ & $(-2.37)$ \\
\hline Productivity t-1 Euros & $-13792.1^{* * *}$ & $(-7.58)$ \\
\hline Human capital t-1 Euros & $-10126.5^{* * *}$ & $(-44.00)$ \\
\hline Trade $\mathrm{t}-1 \%$ of turnover & $-0.0293^{* * *}$ & $(-14.20)$ \\
\hline Subsidies $\mathrm{t}-1 \%$ of production & $-0.000724^{* * *}$ & $(-6.39)$ \\
\hline Part time employees $\mathrm{t}-1 \%$ of employees & $0.0392^{* * *}$ & (18.03) \\
\hline German ownership & $0.0922^{* * *}$ & $(17.29)$ \\
\hline Foreign ownership & $-0.0922^{* * *}$ & $(-17.29)$ \\
\hline East Germany & $0.0290^{* * *}$ & $(4.62)$ \\
\hline West Germany & $-0.0290^{* * *}$ & $(-4.62)$ \\
\hline Single business & $0.0679^{* * *}$ & $(8.90)$ \\
\hline Corporate entity & $-0.0679^{* * *}$ & $(-8.90)$ \\
\hline Other branches of industry & $0.308^{* * *}$ & $(40.89)$ \\
\hline R\&D-intensive branches of industry & $-0.308^{* * *}$ & $(-40.89)$ \\
\hline Observations & 16587 & \\
\hline
\end{tabular}


Table A5: Descriptive Statistics for Companies with and without R\&D Staff 2010

\begin{tabular}{|c|c|c|c|}
\hline & {$[0] \mathrm{No}$} & [1]Yes & Total \\
\hline \multirow[t]{2}{*}{ Occurrence of R\&D } & 0 & 1 & 0.345 \\
\hline & (0) & (0) & $(0.475)$ \\
\hline \multirow[t]{2}{*}{ Occurrence of R\&D t-1 } & 0.0368 & 0.920 & 0.341 \\
\hline & $(0.188)$ & $(0.271)$ & $(0.474)$ \\
\hline \multirow[t]{2}{*}{ Turnover $\mathrm{t} \% \mathrm{t}-1$} & 0.117 & 0.157 & 0.131 \\
\hline & $(0.349)$ & $(0.443)$ & $(0.385)$ \\
\hline \multirow[t]{2}{*}{ Turnover of sector $\mathrm{t} \% \mathrm{t}-1$} & 0.0519 & 0.0780 & 0.0609 \\
\hline & $(0.0705)$ & $(0.0639)$ & $(0.0694)$ \\
\hline \multirow[t]{2}{*}{ Persons employed } & 136.4 & 533.4 & 273.3 \\
\hline & (303.9) & (3377.8) & $(2007.6)$ \\
\hline \multirow[t]{2}{*}{ Persons employed squared } & 110986.2 & 11692096.1 & 4105056.1 \\
\hline & $(1711900.3)$ & (375329907.7) & $(220477204.3)$ \\
\hline \multirow{2}{*}{ Surplus $t-1 \%$ of production } & 0.00578 & -0.00212 & 0.00305 \\
\hline & $(0.117)$ & $(0.134)$ & $(0.123)$ \\
\hline \multirow[t]{2}{*}{ Interest $\mathrm{t}-1 \%$ of production } & 0.0104 & 0.0113 & 0.0107 \\
\hline & $(0.0144)$ & $(0.0183)$ & $(0.0159)$ \\
\hline \multirow[t]{2}{*}{ Productivity t-1 Euros } & 53230.6 & 63009.2 & 56603.0 \\
\hline & $(111505.7)$ & $(102151.8)$ & $(108467.4)$ \\
\hline \multirow[t]{2}{*}{ Human capital t-1 Euros } & 36271.1 & 46326.0 & 39738.8 \\
\hline & $(13487.4)$ & $(14501.3)$ & $(14646.8)$ \\
\hline \multirow[t]{2}{*}{ Trade $\mathrm{t}-1 \%$ of turnover } & 0.0468 & 0.0766 & 0.0571 \\
\hline & $(0.116)$ & $(0.137)$ & $(0.124)$ \\
\hline \multirow[t]{2}{*}{ Subsidies $\mathrm{t}-1 \%$ of production } & 0.000590 & 0.00142 & 0.000877 \\
\hline & $(0.00890)$ & $(0.00922)$ & $(0.00902)$ \\
\hline \multirow{2}{*}{ Part time employees $\mathrm{t}-1 \%$ of employees } & 0.125 & 0.0845 & 0.111 \\
\hline & $(0.146)$ & $(0.0908)$ & $(0.131)$ \\
\hline \multirow[t]{2}{*}{ German ownership } & 0.910 & 0.818 & 0.878 \\
\hline & $(0.287)$ & $(0.386)$ & $(0.327)$ \\
\hline \multirow[t]{2}{*}{ Foreign ownership } & 0.0903 & 0.182 & 0.122 \\
\hline & $(0.287)$ & $(0.386)$ & $(0.327)$ \\
\hline \multirow[t]{2}{*}{ East Germany } & 0.187 & 0.163 & 0.179 \\
\hline & $(0.390)$ & $(0.369)$ & $(0.383)$ \\
\hline \multirow[t]{2}{*}{ West Germany } & 0.813 & 0.837 & 0.821 \\
\hline & $(0.390)$ & $(0.369)$ & $(0.383)$ \\
\hline \multirow[t]{2}{*}{ Single business } & 0.341 & 0.278 & 0.319 \\
\hline & $(0.474)$ & $(0.448)$ & $(0.466)$ \\
\hline \multirow[t]{2}{*}{ Corporate entity } & 0.659 & 0.722 & 0.681 \\
\hline & $(0.474)$ & $(0.448)$ & $(0.466)$ \\
\hline \multirow[t]{2}{*}{ Other branches of industry } & 0.742 & 0.429 & 0.634 \\
\hline & $(0.438)$ & $(0.495)$ & $(0.482)$ \\
\hline \multirow{2}{*}{ R\&D-intensive branches of industry } & 0.258 & 0.571 & 0.366 \\
\hline & $(0.438)$ & $(0.495)$ & $(0.482)$ \\
\hline Observations & 15736 & & \\
\hline
\end{tabular}

mean coefficients; sd in parentheses.

Source: FDZ, KSE, own calculations. 
Table A6: Differences in Means for Companies with and without R\&D in 2010

\begin{tabular}{|c|c|c|}
\hline & $\begin{array}{c}(1) \\
\text { Means }\end{array}$ & \\
\hline Occurrence of R\&D t-1 & $-0.883^{* * *}$ & $(-238.95)$ \\
\hline Turnover $\mathrm{t} \% \mathrm{t}-1$ & $-0.0405^{* * *}$ & $(-6.28)$ \\
\hline Turnover of sector $\mathrm{t} \% \mathrm{t}-1$ & $-0.0260^{* * *}$ & $(-22.74)$ \\
\hline Persons employed & $-396.9^{* * *}$ & $(-11.84)$ \\
\hline Persons employed squared & $-11581110.0^{* *}$ & $(-3.13)$ \\
\hline Surplus $\mathrm{t}-1 \%$ of production & $0.00789^{* * *}$ & (3.82) \\
\hline Interest $\mathrm{t}-1 \%$ of production & $-0.000922^{* * *}$ & $(-3.47)$ \\
\hline Productivity t-1 Euros & $-9778.6^{* * *}$ & $(-5.38)$ \\
\hline Human capital t-1 Euros & $-10054.8^{* * *}$ & $(-43.30)$ \\
\hline Trade $\mathrm{t}-1 \%$ of turnover & $-0.0298^{* * *}$ & $(-14.40)$ \\
\hline Subsidies t $-1 \%$ of production & $-0.000831^{* * *}$ & $(-5.50)$ \\
\hline Part time employees $\mathrm{t}-1 \%$ of employees & $0.0410^{* * *}$ & (18.79) \\
\hline German ownership & $0.0915^{* * *}$ & $(16.81)$ \\
\hline Foreign ownership & $-0.0915^{* * *}$ & $(-16.81)$ \\
\hline East Germany & $0.0249^{* * *}$ & $(3.87)$ \\
\hline West Germany & $-0.0249^{* * *}$ & $(-3.87)$ \\
\hline Single business & $0.0631^{* * *}$ & (8.07) \\
\hline Corporate entity & $-0.0631^{* * *}$ & $(-8.07)$ \\
\hline Other branches of industry & $0.313^{* * *}$ & $(40.66)$ \\
\hline R\&D-intensive branches of industry & $-0.313^{* * *}$ & $(-40.66)$ \\
\hline Observations & 15736 & \\
\hline
\end{tabular}




\section{References}

Aghion, P., P. Askenazy, N. Berman, G. Cette and L. Eymard (2012). "CREDIT CONSTRAINTS AND THE CYCLICALITY OF R\&D INVESTMENT: EVIDENCE FROM FRANCE." Journal of the European Economic Association 10(5): 1001-1024.

Aghion, P. and G. Saint-Paul (1998). "VIRTUES OF BAD TIMES Interaction Between Productivity Growth and Economic Fluctuations " Macroeconomic Dynamics 2(3): 322-344.

Arqué-Castells, P. (2013). "Persistence in R\&D Performance and its Implications for the Granting of Subsidies." Review of Industrial Organization 43(3): 193-220.

Arvanitis, S. and M. Woerter (2013). "Firm characteristics and the cyclicality of R\&D investments." Industrial and Corporate Change.

Barlevy, G. (2007). "On the Cyclicality of Research and Development." American Economic Review 97(4): 1131-1164.

Belitz, H., A. Eickelpasch and A. Lejpras (2010). "Technologieoffene Förderung - Zentrale Stütze der Industrieforschung in Ostdeutschland." Wochenbericht des DIW Berlin 77(51/52): 2 - 10.

Brockhoff, K. K. and A. W. Pearson (1998). "R\&D Budgeting Reactions to a Recession." MIR: Management International Review 38(4): 363-376.

Brown, J. R., S. M. Fazzari and B. C. Petersen (2009). "Financing Innovation and Growth: Cash Flow, External Equity, and the 1990s R\&D Boom." The Journal of Finance 64(1): 151-185.

Cefis, E. (2003). "Is there persistence in innovative activities?" International Journal of Industrial Organization 21(4): 489-515.

Cohen, W. M. and S. Klepper (1996). "A Reprise of Size and R \& D." The Economic Journal 106(437): 925951.

Cohen, W. M. and D. A. Levinthal (1989). "Innovation and Learning: The Two Faces of R \& D." The Economic Journal 99(397): 569-596.

Comin, D. and M. Gertler (2006). "Medium-Term Business Cycles." The American Economic Review 96(3): 523-551.

Cook, D. O., R. Kieschnick and B. D. McCullough (2008). "Regression analysis of proportions in finance with self selection." Journal of Empirical Finance 15(5): 860-867.

Davis, S. J. and J. Haltiwanger (1990). Gross Job Creation and Destruction: Microeconomic Evidence and Macroeconomic Implications. NBER Macroeconomics Annual 1990. O. J. Blanchard and S. Fischer. Cambridge MA, MIT Press. 5: 123 -186.

DIHK (2009). Wirtschaftslage und Erwartungen. Ergebnisse der DIHK-Umfrage bei den Industrie- und Handelskammern Jahresbeginn 2009. DIHK. Berlin.

Dreger, C., S. Kooths, S. Weber and F. Zinsmeister (2008). "Herbstgrundlinien: realwirtschaftliche Auswirkungen der Finanzkrise beherrschbar " Wochenbericht des DIW Berlin(41 ): 612-627.

Eickelpasch, A. (2012). "Research-Based Companies Perform Better." DIW Economic Bulletin 2(10): 3-14.

Eickelpasch, A. and A. Vogel (2011). "Determinants of the export behaviour of German business services companies." The Service Industries Journal 31(4): 513-526.

Filippetti, A. and D. Archibugi (2011). "Innovation in times of crisis: National Systems of Innovation, structure, and demand." Research Policy 40(2): 179-192.

Flaig, G. and M. Stadler (1994). "Success breeds success. The dynamics of the innovation process." Empirical Economics 19(1): 55-68.

Francois, P. and H. Lloyd-Ellis (2009). "Schumpeterian cycles with pro-cyclical R\&D." Review of Economic Dynamics 12(4): 567-591.

Fritsch, M., B. Görzig, O. Hennchen and A. Stephan (2004). "Cost structure surveys for Germany." Schmollers Jahrbuch 124 (4): 557-566. 
Galan, J. I. and M. J. Sanchez (2006). "Influence of industry R\&D intensity on corporate product diversification: interaction effect of free cash flow." Industrial and Corporate Change 15(3): 531547.

Gehrke, B., C. Rammer, R. Frietsch and P. Neuhäusler (2010). Listen wissens- und technologieintensiver Güter und Wirtschaftszweige. Zwischenbericht zu den NIW/ISI/ZEW-Listen 2010/2011 Studien zum deutschen Innovationssystem 19-2010. E. F. u. I. (EFI). Hannover, Karlsruhe, Mannheim.

Grave, B. and A. Kladroba (2013). Entwicklungs- und Nutzungsdauer von Forschung und Entwicklung im Wirtschaftssektor. FuE-Datenreport 2013. Analysen und Vergleiche. A. Kladroba and G. Stenke. Essen, Wissenschaftsstatistik GmbH: 49-52.

Guellec, D. and E. Ioannidis (1999). "CAUSES OF FLUCTUATIONS IN R\&D EXPENDITURES A QUANTITATIVE ANALYSIS." OECD Economic Studies 29(II).

Kladroba, A. (2013). FuE-Datenreport 2013. Tabellen und Daten. W. G. i. S. f. d. Wissenschaft. Essen, Wissenschaftsstatisitk $\mathrm{GmbH}$ im Stifterverband für die Wissenschaft

Kladroba, A. and G. Stenke (2011). "Wie krisenfest ist Forschung und Entwicklung? Auswirkungen der Wirtschafts- und Finanzkrise 2009 auf die FuE-Aktivitäten der deutschen Wirtschaft." Vierteljahrshefte zur Wirtschaftsforschung 80(3): 55-72.

Lee, C.-Y. (2003). "A simple theory and evidence on the determinants of firm R\&D." Economics of Innovation and New Technology 12(5): 385-395.

Mánez, J. A., M. E. Rochina-Barrachina, A. Sanchis and J. A. Sanchis (2009). "THE ROLE OF SUNK COSTS IN THE DECISION TO INVEST IN R\&D." The Journal of Industrial Economics 57(4): 712-735.

Mansfield, E. (1968). Industrial Research and Technological Innovation: An Econometric Analysis. New York, Norton.

Nahm, M. (2011). "Inward-FATS - Auslandskontrollierte Unternehmen in Deutschland 2008." Wirtschaft und Statistik(9): 899 - 906.

Nelson, R. R. and S. G. Winter (1982). An Evolutionary Theory of Economic Change. Cambridge MA, Havard University Press.

OECD, Ed. (2002). Frascati Manual. Proposed Standard Practice for Surveys on Research and Experimental Development. Paris.

Ouyang, M. (2010). "On the Cyclicality of R\&D." Review of Economics and Statistics 93(2): 542-553.

Papke, L. E. and J. M. Wooldridge (1996). "Econometric Methods for Fractional Response Variables With an Application to 401 (K) Plan Participation Rates." Journal of Applied Econometrics 11(6): 619 632.

Peters, B. (2009). "Persistence of innovation: stylised facts and panel data evidence." The Journal of Technology Transfer 34(2): 226-243.

Rammer, C. (2011). "Auswirkungen der Wirtschaftskrise auf die Innovationstätigkeit der Unternehmen in Deutschland." Vierteljahrshefte zur Wirtschaftsforschung 80(3): 13-34.

Rammer, C., H. Penzkofer, A. Stephan and C. Grenzmann (2004). FuE- und Innovationsverhalten von KMU und Großunternehmen unter dem Einfluss der Konjunktur. Mannheim, München, Berlin, Essen.

Raymond, W., P. Mohnen, F. Palm and S. S. van der Loeff (2010). "Persistence of Innovation in Dutch Manufacturing: Is It Spurious?" Review of Economics and Statistics 92(3): 495-504.

Rogers, M. (2004). "Networks, Firm Size and Innovation." Small Business Economics 22(2): 141 - 153.

Rosenberg, N. (1974). "Science, Invention and Economic Growth." The Economic Journal 84(333): 90108.

Schumpeter, J. A. (1934). The Theory of Economic Development: An Inquiry into Profits, Capital, Credit, Interest, and the Business Cycle. Cambridge MA, Harvard Economic Studies.

Shleifer, A. (1986). "Implementation Cycles." Journal of Political Economy 94(6): 1163-1190. 
Smolny, W. (2003). "Determinants of innovation behaviour and investment estimates for west-german manufacturing firms." Economics of Innovation and New Technology 12(5): 449-463.

Statistisches Bundesamt (2012). Qualitätsbericht. Kostenstrukturerhebung im Verarbeitenden Gewerbe, im Bergbau sowie in der Gewinnung von Steinen und Erden. Kostenstrukturerhebung. Wiesbaden, Statistisches Bundesamt.

Sutton, J. (1991). Sunk Costs and Market Structure. Price Competition, Advertising, and the Evolution of Concentration. Cambridge, The MIT Press.

Triguero, Á. and D. Córcoles (2013). "Understanding innovation: An analysis of persistence for Spanish manufacturing firms." Research Policy 42(2): 340-352.

Wagner, J. (2001). "A Note on the firm Size - Export Relationship." Small Business Economics 17: 229 237.

Wälde, K. and U. Woitek (2004). "R\&D expenditure in G7 countries and the implications for endogenous fluctuations and growth." Economics Letters 82(1): 91-97.

Zühlke, S., M. Zwick, S. Scharnhorst and T. Wende (2004). "The research data centres of the Federal Statistical Office and the statistical offices of the Länder." Schmollers Jahrbuch 124 (4): 567-578. 